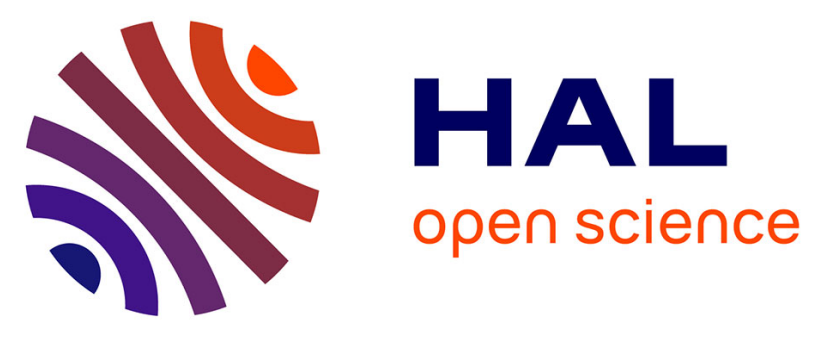

\title{
Optical-electrical simulation of organic solar cells: excitonic modeling parameter influence on electrical characteristics
}

Wilfried Vervisch, Stéphane Biondo, Guillaume Rivière, David Duche, Ludovic Escoubas, Philippe Torchio, Jean-Jacques Simon, Judikaël Le Rouzo

\section{To cite this version:}

Wilfried Vervisch, Stéphane Biondo, Guillaume Rivière, David Duche, Ludovic Escoubas, et al.. Optical-electrical simulation of organic solar cells: excitonic modeling parameter influence on electrical characteristics. Applied Physics Letters, 2011, 98 (25), 10.1063/1.3582926 . hal-01757663

\section{HAL Id: hal-01757663 \\ https://hal-amu.archives-ouvertes.fr/hal-01757663}

Submitted on 15 Nov 2021

HAL is a multi-disciplinary open access archive for the deposit and dissemination of scientific research documents, whether they are published or not. The documents may come from teaching and research institutions in France or abroad, or from public or private research centers.
L'archive ouverte pluridisciplinaire HAL, est destinée au dépôt et à la diffusion de documents scientifiques de niveau recherche, publiés ou non, émanant des établissements d'enseignement et de recherche français ou étrangers, des laboratoires publics ou privés. 


\title{
Optical-electrical simulation of organic solar cells: excitonic modeling parameter influence on electrical characteristics
}

\author{
Wilfried Vervisch, ${ }^{\text {a) }}$ Stéphane Biondo, Guillaume Rivière, David Duché, Ludovic Escoubas, \\ Philippe Torchio, Jean-Jacques Simon, and Judikaël Le Rouzo \\ IM2NP, Aix-Marseille Université, France and IM2NP, CNRS, UMR 6242 (Marseille-Toulon), Faculté des \\ Sciences et Techniques, Campus de Saint-Jérôme, Avenue Escadrille Normandie Niemen-Service \\ 231, F-13397 Marseille Cedex, France
}

(Received 22 November 2010; accepted 31 March 2011; published online 22 June 2011)

\begin{abstract}
This paper deals with Organic Solar Cells (OSCs) simulation using finite element method. Optical modeling is performed via Finite Difference Time Domain method whereas the continuity and Poisson's equations are solved to obtain electrical characteristics of the OSC. In this work, simulation results point out the influence of physical parameters such as the exciton diffusion coefficient or the exciton lifetime on OSC performances. The comparison of modeling results and experimental measurement allows the exciton recombination, dissociation rate and lifetime to be determinated. (C) 2011 American Institute of Physics. [doi:10.1063/1.3582926]
\end{abstract}

Organic Solar Cell (OSC) technology seems to be a promising solution for the power supply of mobile electronic components. Beyond the advantageous properties such as their mechanical flexibility, these components fulfil the criteria to strongly reduce manufacturing costs. However, organic devices do not allow obtaining conversion efficiencies in the same order of magnitude as the silicon ones. Therefore, some research groups are working on OSC architectures, by using modeling, with the aim of improving their conversion efficiencies $^{1,2}$. In order to avoid many experiments, the device behavior simulation is a real way to provide designs of solar cells ${ }^{3}$. In this paper, we present a simulation method based on the Finite Element Method (FEM) which computes the optical and electrical characteristics of OSC. Taking into account all physical parameters such as complex optical index, density of states, carrier mobilities, this numeric method allows computing the $\mathrm{J}-\mathrm{V}$ characteristics and efficiencies of OSC. The aim of this paper is to model the influence of several physical parameters on the OSC optical and electrical performances.

A $1 \mathrm{~cm}^{2}$ OSC is considered in this paper. Its structure (Fig. 1(a)) is a planar stacked multilayer. On the top of the OSC is laid down an anode layer made of indium tin oxide (ITO) $(150 \mathrm{~nm}$ thick) where the solar light waves strike in normal incidence. The following subsequent layers are a thin layer (30 $\mathrm{nm}$ thick) of poly(3,4-ethylenedioxythiopene): poly(styrenesulfonate) (PEDOT:PSS), the active layer which is a blend of poly(3-hexylthiophene) and methanofullerene [6,6]-phenyl- $\mathrm{C}_{61}$-butyric acid methyl ester (P3HT:PCBM) (1:1 weight-ratio) and the aluminum cathode (100 nm thick). The modeling of the OSC is performed according to the following conditions:

-electrical: reflective (Neumann's) boundaries (left and right sides on Fig. 1(a)). This hypothesis means that OSC is assumed infinite.

-optical: periodic boundaries (left and right sides on Fig. 1(a)) and Perfectly Matched Layer on the top and the bottom.

In the optical simulation, the exciton generation rate is computed according to the following expression:

$$
\mathrm{G}(\mathrm{z})=\eta \frac{\sigma_{\mathrm{c}}}{2} \frac{|\mathrm{E}(\mathrm{z})|^{2}}{\hbar \nu},
$$

where $\sigma_{\mathrm{c}}|\mathrm{E}(\mathrm{z})|^{2} / 2$ is the power density, $\eta$ is the quantum yield (assumed to be equal to 1 ), $\sigma_{\mathrm{c}}$ the conductivity constant of the active layer, $\mathrm{E}(\mathrm{z})$ the electromagnetic field versus $\mathrm{z}, \hbar$ the Planck constant, $\nu$ the wave frequency. The computation in the OSC structure is based on the Finite Difference Time Domain (FDTD) method ${ }^{4}$ which solves the Maxwell's equations. The light source (solar light AM 1.5) is placed above the ITO layer at a distance of $2 \mu \mathrm{m}$ in order to avoid any interference phenomenon. The air and device FDTD meshing is constituted of triangles. The triangle side sizes are ranging between 3 and $10 \mathrm{~nm}$. All optical constants are taken into account for each material composing the stack ${ }^{5}$.

The optical results, in particular the exciton generation rate $G(z)$, are then introduced in the electrical simulation. Continuity equations are solved using FEM, considering the physical parameters of each material composing the stack and keeping the same meshing as the optical one. Material work functions and bandgap values have been extracted from the paper written by Kim et al. ${ }^{6}$. The OSC electrical model is described by using a metal-insulator-metal scheme ${ }^{3,7}$. Two Schottky diodes are considered between the PEDOT:PSS and the active layer and between the active layer (P3HT:PCBM blend) and the aluminum electrode. In the literature, Cheyns et $a l .{ }^{8}$ have reported for instance shunts paths connecting contacts, Li et al. $^{9}$ have shown the thermal annealing effect on the metal-polymer interface, which influence the barrier

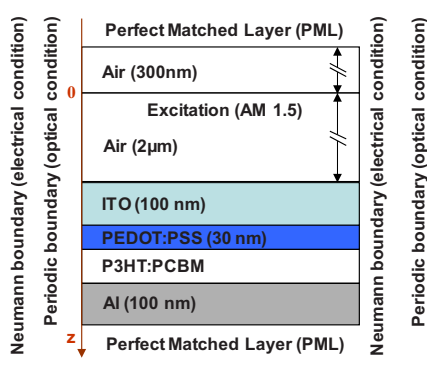

(a)
${ }^{a)}$ Electronic mail: wilfried.vervisch@univ-cezanne.fr.

FIG. 1. (Color online) (a) OSC structure and electrical and optical boundary conditions. (b) Energy levels (in eV) of materials. 
TABLE I. Evolution of electrical characteristics $\left[\mathrm{V}_{\mathrm{oc}}(\mathrm{V}), \mathrm{J}_{\mathrm{sc}}\left(\mathrm{mA} . \mathrm{cm}^{-2}\right)\right.$, FF $(\%)$, and PCE (\%)] versus the parameter values $D_{x}\left(\mathrm{~cm}^{2} \cdot \mathrm{s}^{-1}\right), \sigma\left(\mathrm{cm}^{2}\right), \nu$ $\left(\mathrm{cm} \cdot \mathrm{s}^{-1}\right)$, and $\left.\tau_{x}(\mathrm{~s})\right]$.

\begin{tabular}{|c|c|c|c|c|}
\hline $\begin{array}{l}-\triangle \text { FF } \\
-\square-\text { Jsc } \\
-\nabla-\text { PCE } \\
-\circ-\text { Voc }\end{array}$ & 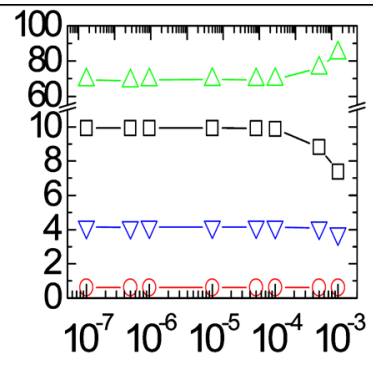 & 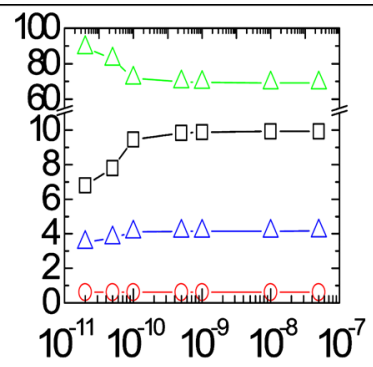 & 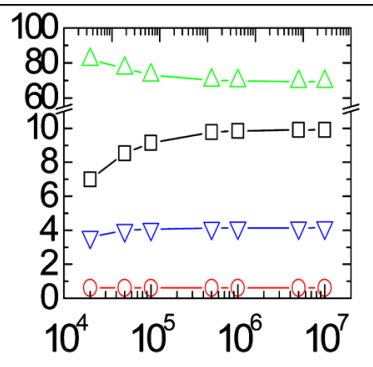 & 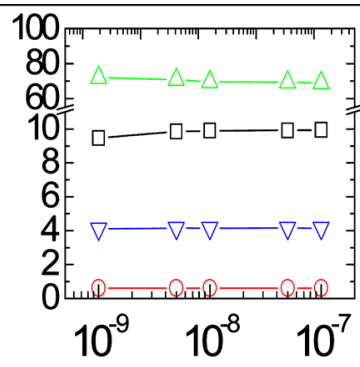 \\
\hline & $\begin{array}{l}\text { Diffusion length } \mathrm{D}_{\mathrm{x}} \\
\text { (Eq. (3)) }\end{array}$ & $\begin{array}{l}\text { Cross section } \sigma_{\mathrm{x}-\mathrm{n}}, \sigma_{\mathrm{x}-\mathrm{p}} \\
(\text { Eq. (7)) }\end{array}$ & $\begin{array}{l}\text { Velocity } \nu_{\mathrm{x}}, \nu_{\mathrm{n}}, \nu_{\mathrm{p}} \\
(\text { Eq. (7)) }\end{array}$ & $\begin{array}{l}\text { Lifetime } \tau_{\mathrm{x}} \\
\text { (Eq. (3)) }\end{array}$ \\
\hline
\end{tabular}

heights. In this paper, we assume an ideal model of the two diodes, no contact between PCBM and PEDOT, and no contact between P3HT and aluminum. On the anode side, the Schottky diode barrier is equal to the difference between the PEDOT:PSS work function and the P3HT Fermi level. On the cathode side, the Schottky barrier is equal to the difference between the PCBM Fermi level and the aluminum work function (Fig. 1(b)). Since the two organic materials (P3HT and PCBM) carrier depleted, we assume that the P3HT and PCBM Fermi levels are situated in the middle of their bandgap. Taking into account the absorption limit measured for P3HT:PCBM 1:1 blend $(\lambda=650 \mathrm{~nm})^{10}$, the P3HT:PCBM bandgap is assumed to be equal to $1.8 \mathrm{eV}$. Both P3HT and PCBM organic materials are disordered semiconductors, in which the charge transport is mainly governed by hopping in energetically broadened Gaussian density of states ${ }^{1}$. Besides, the charge carrier transport can be described as a stochastic hopping process between strongly localized states. Thus, the Poole-Frenkel mobility, depends on the temperature $\mathrm{T}$ and the electric field ${ }^{12} \mathrm{~F}$ in Eq. (2):

$$
\mu(\mathrm{F}, \mathrm{T})=\mu_{0} \exp \left(-\frac{\mathrm{E}_{\mathrm{a}}}{\mathrm{k}_{\mathrm{B}} \mathrm{T}}\right) \exp \left(\frac{\sqrt{\mathrm{F}}}{\mathrm{T}}\right),
$$

with $\mu_{0}$ the mobility without the electric field $\mathrm{F}, \mathrm{E}_{\mathrm{a}}$ the activation energy, $\mathrm{k}_{\mathrm{B}}$ the Boltzmann constant. Equations which can be solved using FEM and describe the electrical model, are the Poisson's equation and the continuity equations of excitons, electrons and holes. Added to these equations, the recombination by Shockley-Read-Hall model ${ }^{13}$ (SRH), the diffusion and generation processes of carriers or excitons are taken into account as following in Eqs. (3)-(5):

$$
\begin{gathered}
\frac{\partial \mathrm{x}}{\partial \mathrm{t}}=\mathrm{G}(\mathrm{z})+\mathrm{R}-\mathrm{D}-\frac{\mathrm{x}-\mathrm{x}_{\mathrm{eq}}}{\tau_{\mathrm{x}}}-\frac{1}{\mathrm{q}} \nabla\left(-\mathrm{D}_{\mathrm{x}} \nabla \mathrm{x}\right), \\
\frac{\partial \mathrm{n}}{\partial \mathrm{t}}=\mathrm{D}-\mathrm{R}-\frac{\mathrm{n}-\mathrm{n}_{\mathrm{eq}}}{\tau_{\mathrm{n}}}-\frac{1}{\mathrm{q}} \nabla\left(-\mathrm{qn} \mu_{\mathrm{n}} \nabla \phi-\mathrm{k}_{\mathrm{B}} \mathrm{T} \mu_{\mathrm{n}} \nabla \mathrm{n}\right), \\
\frac{\partial p}{\partial t}=\mathrm{D}-\mathrm{R}-\frac{\mathrm{p}-\mathrm{p}_{\mathrm{eq}}}{\tau_{\mathrm{p}}}-\frac{1}{\mathrm{q}} \nabla\left(-\mathrm{qn} \mu_{\mathrm{p}} \nabla \phi+\mathrm{k}_{\mathrm{B}} \mathrm{T} \mu_{\mathrm{p}} \nabla \mathrm{p}\right),
\end{gathered}
$$

with:

$-\mathrm{x}, \mathrm{x}_{\mathrm{eq}}, \mathrm{n}, \mathrm{n}_{\mathrm{eq}}, \mathrm{p}, \mathrm{p}_{\mathrm{eq}}$ the respective excitons, excitons equilibrium, electrons, electrons equilibrium, holes, and holes equilibrium densities,

$-\mu_{\mathrm{x}}, \mu_{\mathrm{n}}, \mu_{\mathrm{p}}$ the respective mobilities of excitons, electrons, and holes,

$-\tau_{\mathrm{x}}, \tau_{\mathrm{n}}, \tau_{\mathrm{p}}$, respectively the lifetimes of the exciton, electron, and hole,

$-\mathrm{D}_{\mathrm{x}}$ exciton diffusion coefficient in Eq. (3), $\phi$ the electrical potential in Eqs. (4) and (5),

$-\mathrm{G}(\mathrm{z})$ is the exciton generation rate,

$-\mathrm{D}$ the exciton dissociation rate,

$-\left(\mathrm{x}-\mathrm{x}_{\mathrm{eq}}\right) / \tau_{\mathrm{x}}$ corresponds to the exciton recombination (radiative and nonradiative recombination term),

$-\mathrm{R}$ the bimolecular recombination rate according to the Langevin model ${ }^{14}$ which is defined in Eq. (6):

$$
\mathrm{R}=\frac{\mathrm{q}}{\varepsilon \varepsilon_{0}}\left(\mu_{\mathrm{n}}+\mu_{\mathrm{p}}\right)\left(\mathrm{np}-\mathrm{n}_{\mathrm{i}}^{2} \frac{\mathrm{x}}{\mathrm{x}_{\mathrm{eq}}}\right)
$$

with $\varepsilon$ and $\varepsilon_{0}$ the dielectric constants of the material and the vacuum, $\mathrm{n}_{\mathrm{i}}$ the intrinsic density of electrons and holes. For the dissociation rate, we use the Staudigel's expression ${ }^{15}$ (Eq. (7)) rather than those related to the Onsager theory ${ }^{16}$.

$$
\mathrm{D}=\left(\nu_{\mathrm{x}}+\nu_{\mathrm{n}}\right) \sigma_{\mathrm{x}-\mathrm{n}} \mathrm{nx}+\left(\nu_{\mathrm{x}}+\nu_{\mathrm{p}}\right) \sigma_{\mathrm{x}-\mathrm{p}} \mathrm{px},
$$

where $\nu_{\mathrm{x}}, \nu_{\mathrm{n}}, \nu_{\mathrm{p}}$ are respectively the exciton, electron and hole velocities and $\sigma_{\mathrm{x}-\mathrm{n}}, \sigma_{\mathrm{x}-\mathrm{p}}$ reaction cross sections between carriers and excitons.

To compute $\mathrm{J}-\mathrm{V}$ characteristics at $300 \mathrm{~K}$, a bias voltage is applied between the anode and the cathode. The influence of the various exciton parameters is studied and compared to experimental measurement published by $\mathrm{Li}$ et $a l .{ }^{9}$. More precisely, the exciton parameters such as the exciton dissociation rate $\mathrm{D}$ and the exciton recombination are varied whereas the exciton generation $\mathrm{G}(\mathrm{z})$, directly computed by the FDTD method, and the bimolecular recombination rate $\mathrm{R}$ are fixed. Indeed, this bimolecular recombination rate depends mainly on carrier mobilities (Eq. (6)). Melzer et al. ${ }^{17}$ study on electron and hole mobilities in P3HT:PCBM 1:1 blends as a function of annealing temperature allowed the values of hole mobilities (almost $10^{-8} \mathrm{~m}^{2} \cdot \mathrm{V}^{-1} \cdot \mathrm{s}^{-1}$ ) and electron mobilities $\left(3 \times 10^{-7} \mathrm{~m}^{2} \cdot \mathrm{V}^{-1} \cdot \mathrm{s}^{-1}\right)$ to be obtained in the case of a blend annealed at $120{ }^{\circ} \mathrm{C}$. From the work of Shuttle et al. ${ }^{18}$ in accordance with carrier density generation results, the lifetimes of the electron and hole, $\tau_{\mathrm{n}}$ and $\tau_{\mathrm{p}}$ are taken equal to $10^{-5} \mathrm{~s}^{19}$

Different exciton parameters studied in a batch of simulations are presented in Table I (P3HT:PCBM blend thickness is equal to $80 \mathrm{~nm}$ ). As regard the exciton dissociation rate influence (Eq. (7)), we can observe a $\mathrm{J}_{\mathrm{sc}}$ increase with the velocities $\nu_{\mathrm{x}}, \nu_{\mathrm{n}}, \nu_{\mathrm{p}}$ and the reaction cross section $\sigma_{\mathrm{x}-\mathrm{n}}$, 
TABLE II. Comparison between simulation (s) and experimental (e) electrical characteristics.

\begin{tabular}{ccccccc}
\hline \hline \multirow{2}{*}{$\begin{array}{c}\text { Thickness } \\
(\mathrm{nm})\end{array}$} & \multicolumn{3}{c}{48} & & \multicolumn{3}{c}{55} \\
\cline { 2 - 3 } \cline { 5 - 6 } & $(\mathrm{s})$ & $(\mathrm{e})$ & & $(\mathrm{s})$ & $(\mathrm{e})$ \\
\hline $\mathrm{V}_{\mathrm{oc}}(\mathrm{V})$ & 0.61 & 0.61 & & 0.62 & 0.62 \\
$\mathrm{~J}_{\mathrm{sc}}\left(\mathrm{mA} . \mathrm{cm}^{-2}\right)$ & 7.76 & 7.79 & & 9.92 & 9.95 \\
$\mathrm{FF}(\%)$ & 0.69 & 0.67 & & 0.69 & 0.63 \\
$\mathrm{PCE}(\%)$ & 3.19 & 3.19 & & 4.14 & 3.85 \\
\hline \hline
\end{tabular}

$\sigma_{\mathrm{x}-\mathrm{p}}$. The influence of these parameters demonstrates that an efficient dissociation rate, which means an improvement of the carrier creation process, leads to a $\mathrm{J}_{\mathrm{sc}}$ increase. A slight increase of Power Conversion Efficiency (PCE) is observed for increasing values of $\nu, \sigma$. However, we observe a constant value of PCE for the higher values of $\nu, \sigma$, which may be attributed to the compensation between the Fill Factor $(\mathrm{FF})$ value decrease and the short-circuit current density $\left(\mathrm{J}_{\mathrm{sc}}\right)$ value increase. In the case of the exciton recombination, only the exciton lifetime $\tau_{x}$ has been studied. We notice that an exciton lifetime $\tau_{\mathrm{x}}$ increase leads to slight $\mathrm{J}_{\mathrm{sc}}$ and PCE increases despite a FF decrease. Simulation results do not show the same behavior for the exciton diffusion coefficient related to the exciton mobility, the higher the coefficient, the lower the $\mathrm{J}_{\mathrm{sc}}$, the FF and the PCE. In this study, the simulation results show almost no influence on the open-circuit voltage $\left(\mathrm{V}_{\mathrm{oc}}\right)$ whatever exciton parameter values. However, the exciton parameters influence on the $\mathrm{J}_{\mathrm{sc}}$ values.

Our aim is now to compare simulation results with experimental results published by Li et al. ${ }^{9}$. Two thicknesses (48 and $55 \mathrm{~nm}$ ) of the blend film have been tested. Table II presents a comparison of the computed electrical characteristic $\left(\mathrm{V}_{\mathrm{oc}}, \mathrm{J}_{\mathrm{sc}}, \mathrm{FF}, \mathrm{PCE}\right)$ and experimental ones measured by Li et al. ${ }^{9}$. The agreement between computed and experimental values has to be underlined. But, whereas computed and experimental values of $\mathrm{V}_{\mathrm{oc}}$ and $\mathrm{J}_{\mathrm{sc}}$ are very close for the two thicknesses, the 55-nm-thick blend PCE is slightly different mainly because a best FF value is obtained by computation. We assume that the difference between FF simulation and experimental measurement comes from the carrier mobilities. We know that the higher the carrier mobility values, the better the FF values. The processing conditions to prepare the organic film are crucial, in particular for the organic material annealing ${ }^{20}$ which influences the mobility values, thus the FF. We have chosen these values because they correspond to the same processing conditions than in $\mathrm{Li}$ et al. ${ }^{9}$ publication, however, these values should still be higher than the experimental values.

In Fig. 2, simulation and experimental results are presented for both P3HT:PCBM blend thicknesses $(48 \mathrm{~nm}, 55$ $\mathrm{nm})$. Simulated and experimental $\mathrm{J}-\mathrm{V}$ curves are similar. Some slight differences appear around bending area due to the FF values, as it was pointed out previously. For such simulations, the exciton lifetime $\tau_{\mathrm{x}}$ was equal to $10^{-9} \mathrm{~s}$, according to values given in the literature ${ }^{21,22}$. The diffusion coefficient $D_{x}$ was fixed to $4 \times 10^{-4} \mathrm{~cm}^{2} . \mathrm{s}^{-1}$ which is in the agreement with the typical organic device diffusion coefficient $^{20,23}$. The reaction cross sections $\sigma_{\mathrm{x}-\mathrm{n}}, \sigma_{\mathrm{x}-\mathrm{p}}$ were equal to $10^{-10} \mathrm{~cm}^{2}$ while the velocity $\nu_{\mathrm{x}}, \nu_{\mathrm{n}}, \nu_{\mathrm{p}}$ were equal to $10^{6} \mathrm{~cm} \cdot \mathrm{s}^{-1}$.

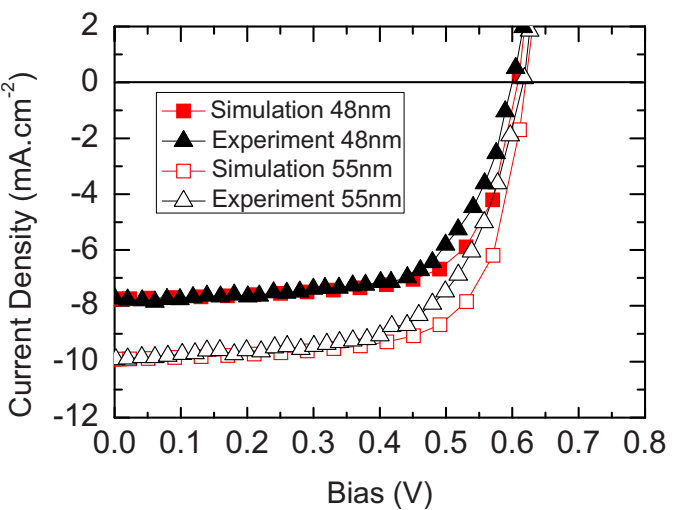

FIG. 2. (Color online) $\mathrm{J}-\mathrm{V}$ simulation and experimental measurements curves.

In summary, we presented an OSC simulation model allowing us to study the influence of excitonic parameters on the electrical characteristics. We demonstrated the influence of the excitonic parameters on the $\mathrm{J}_{\mathrm{sc}}$ values. No influence was observed on the $\mathrm{V}_{\text {oc }}$ which is normal as the $\mathrm{V}_{\mathrm{oc}}$ is mainly influenced by the energy levels of materials. Finally, this OSC simulation model allows by fitting experimental $\mathrm{J}-\mathrm{V}$ characteristics to deduce electrical parameters for $\mathrm{D}_{\mathrm{x}}, \tau_{\mathrm{x}}$, $\nu_{\mathrm{x}}, \nu_{\mathrm{n}}, \nu_{\mathrm{p}}, \sigma_{\mathrm{x}-\mathrm{n}}$, and $\sigma_{\mathrm{x}-\mathrm{p}}$.

${ }^{1}$ D. Duché, L. Escoubas, J.-J. Simon, P. Torchio, W. Vervisch, and F. Flory, Appl. Phys. Lett. 92, 193310 (2008).

${ }^{2}$ J. R. Tumbleston, D.-H. Ko, E. T. Samulski, and R. Lopez, Appl. Phys. Lett. 94, 043305 (2009).

${ }^{3}$ L. J. A. Koster, E. C. P. Smits, V. D. Mihailetchi, and P. W. M. Blom, Phys. Rev. B 72, 085205 (2005).

${ }^{4}$ A. Tavlove, Computational Electrodynamics: The Finite-Difference TimeDomain Method (Arthech House, Norwood, MA, 1995).

${ }^{5}$ F. Monestier, J.-J. Simon, P. Torchio, L. Escoubas, F. Flory, S. Bailly, R. de Bettignies, S. Guillerez, and C. Defranoux, Sol. Energy Mater. Sol. Cells 91, 405 (2007).

${ }^{6}$ J. Y. Kim, K. Lee, N. E. Coates, D. Moses, T. Q. Nguyen, M. Dante, and A. J. Heeger, Science 317, 222 (2007).

${ }^{7}$ N. Sedghi, D. Donaghy, M. Raja, S. Badriya, S. J. Higins, and W. Eccleston, J. Non-Cryst. Solids 352, 1641 (2006).

${ }^{8}$ D. Cheyns, K. Vasseur, C. Rolin, J. Geneo, J. Poortmans, and P. Heremans, Nanotechnology 19, 424016 (2008).

${ }^{9}$ G. Li, V. Shrotriya, Y. Yao, and Y. Yang, J. Appl. Phys. 98, 043704 (2005).

${ }^{10}$ S. Cook, R. Katoh, and A. Furube, J. Phys. Chem. C 113, 2547 (2009).

${ }^{11}$ P. W. M. Blom, V. D. Mihailetchi, L. J. A. Koster, and D. E. Markov, Adv. Mater. (Weinheim, Ger.) 19, 1551 (2007).

${ }^{12}$ J. Frenkel, Phys. Rev. 54, 647 (1938).

${ }^{13}$ W. Shockley and W. T. Read, Jr., Phys. Rev. 87, 835 (1952).

${ }^{14}$ A. Pivrikas, G. Juška, R. Österbacka, M. Westerling, M. Viliunas, K. Arlauskas, and H. Stubb, Phys. Rev. B 71, 125205 (2005).

${ }^{15}$ J. Staudigel, M. Stössel, F. Steuber, and J. Simmerer, J. Appl. Phys. 86, 3895 (1999).

${ }^{16}$ N. C. Giebink, B. E. Lassiter, G. P. Wiederrecht, M. R. Wasielewski, and S. R. Forrest, Phys. Rev. B 82, 155306 (2010).

${ }^{17}$ C. Melzer, E. Koop, V. D. Mihailetchi, and P. W. M. Blom, Adv. Funct Mater. 14, 865 (2004).

${ }^{18}$ C. G. Shuttle, B. O'Regan, A. M. Ballantyne, J. Nelson, D. D. C. Bradley, J. de Mello, and J. R. Durrant, Appl. Phys. Lett. 92, 093311 (2008).

${ }^{19}$ G. Garcia-Belmonte, P. P. Boix, J. Bisquert, M. Sessolo, and H. J. Bolink, Sol. Energy Mater. Sol. Cells 94, 366 (2010).

${ }^{20} \mathrm{C}$. Brabec, V. Dyakonov, and U. Scherf, Organic Photovoltaïcs (WileyVCH, New York, 2008), Chap. B, p. 292.

${ }^{21}$ P. E. Shaw, A. Ruseckas, and I. D. W. Samuel, Adv. Mater. (Weinheim, Ger.) 20, 3516 (2008).

${ }^{22}$ I. G. Scheblykin, A. Yartsev, T. Pullerits, V. Gulbinas, and V. Sundström, J. Phys. Chem. B 111, 6303 (2007).

${ }^{23}$ J. Piris, T. E. Dykstra, A. A. Bakulin, P. H. M. van Loosdrecht, W. Knulst M. T. Trinh, J. M. Schins, and L. D. A. Siebbeles, J. Phys. Chem. C 113, 14500 (2009). 